\title{
Molecular Insights into Glacial Cryoconite Dissolved Organic Matter Evolution Under Dark Conditions During the Ablation Season on the Tibetan Plateau
}

Lin Feng, ${ }^{\dagger} \ddagger$ Yanqing An, ${ }^{\dagger}$ Jianzhong Xu, ${ }^{*}{ }^{\dagger}$ Anne M. Kellerman, ${ }^{\S}$ Martha L. Chacón Patiño, ${ }^{\S}$ Robert G.M. Spencer ${ }^{*}, \S$

†State Key Laboratory of Cryospheric Science, Northwest Institute of Eco-

Environment and Resources, Chinese Academy of Sciences, Lanzhou 730000, China.

${ }^{\star}$ Aba Teachers University, Wenchuan 623002, China.

$\S$ National High Magnetic Field Laboratory Geochemistry Group and Department of Earth, Ocean, and Atmospheric Science, Florida State University, Tallahassee, FL, USA. 


\section{Supplementary information}

\section{DOC concentration and absorbance analyses}

The DOC concentration in each sample was determined using a Vario EL CN analyser (Elementar, Hanau, Germany). Filtered samples were acidified with $100 \mu \mathrm{L}$ of $10 \%$ hydrochloric acid to remove inorganic carbonates. Non-purgeable OC was then oxidized by combusting the sample at $850{ }^{\circ} \mathrm{C}$ in a carrier gas with a controlled $\mathrm{O}_{2}$ concentration, and the evolved $\mathrm{CO}_{2}$ gas was determined using a non-dispersive infrared analyser. The system was calibrated using a potassium hydrogen phthalate standard. The concentration of the potassium hydrogen phthalate ranged from $0.01 \mathrm{mg} \mathrm{C} \mathrm{L}^{-1}$ to $50 \mathrm{mg} \mathrm{C} \mathrm{L}{ }^{-1}$ in this study. We performed this calibration curve daily and tested one standard concentration of the potassium hydrogen phthalate (such as $0.08 \mathrm{mg} \mathrm{C} \mathrm{L} \mathrm{L}^{-1}$, $0.16 \mathrm{mg} \mathrm{C} \mathrm{L}^{-1}$ and $10 \mathrm{mg} \mathrm{C} \mathrm{L}^{-1}$ ) after measurement of four or five samples to verify the accuracy of measurements. The detection limit for DOC was $\sim 50 \mu \mathrm{g} \mathrm{C} \mathrm{L}^{-1}$ defined as three times the standard deviation of low concentration samples. Two replicates were measured for each sample. The reproducibility (the relative deviation from the mean value) was better than $5 \%$.

The UV/Vis absorbance of each sample was measured between 200 and $900 \mathrm{~nm}$ on a UV-visible absorption spectrophotometer (UV-2410PC, Shimadzu, Japan) using a $5 \mathrm{~cm}$ quartz cuvette, with blank-correction using Milli-Q water in an identical cuvette measured alongside the sample. Absorbance spectra were baseline-corrected by subtracting the mean absorbance for the spectral range from $690 \mathrm{~nm}$ to $700 \mathrm{~nm}$. Optical 
density values (i.e., absorbance values) were converted to absorption coefficients by fitting the equation:

$$
a(\lambda)=2.303 \cdot A(\lambda) / L
$$

where $A(\lambda)$ is the measured absorbance for a wavelength $\lambda$, $L$ is the pathlength of the optical cell (here, $\mathrm{L}=0.05 \mathrm{~m}$ ), and 2.303 is the common-to-natural logarithm conversion factor.

\section{Calculation of DOC leaching rates normalized to organic carbon content}

The organic carbon content of cryoconite in LHG glacier were $1.51 \pm 0.51 \mathrm{mg} \mathrm{g}^{-}$

${ }^{1}$ dry weight ${ }^{1}$. The mass of cryoconite used for leaching experiment in this study was $\sim 180 \mathrm{~g}$ of fresh weight in each $250 \mathrm{~mL}$ glass bottles. The water content of fresh cryoconite was $29.10 \pm 0.97 \mathrm{~g}$ per $100 \mathrm{~g}$ fresh cryoconite. According to these basic data, we calculated the DOC leaching rates normalized by TOC based on the following equation:

$$
R_{D O C}^{*}=\frac{R_{D O C} \times V \times T^{*}}{M_{T O C}} \times 100 \%
$$

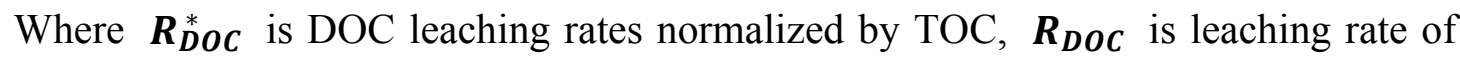
DOC during $\mathrm{d}_{3}$ to $\mathrm{d}_{30}, \boldsymbol{V}$ is Leaching volume in one leaching device $(250 \mathrm{~mL}), \boldsymbol{T}^{*}$ is the total leaching days during the ablation season on TP, $\boldsymbol{T}^{*}=30$ days month ${ }^{-1} \times 3$ months $=90$ days (The ablation season begins at May and ends at October on Tibetan Plateau, half of the ablation season represents only the night time of ablation season), $\boldsymbol{M}_{\text {TOC }}$ is the mass of TOC in cryoconite sediments in one leaching device.

$$
\boldsymbol{R}_{D O C}=\frac{\Delta D O C}{\Delta T}
$$


where $\triangle$ DOC is the variation of DOC concentration between $\mathrm{d}_{3}$ and $\mathrm{d}_{30}, \Delta \mathbf{T}$ is the variation of leaching time during $d_{3}$ to $d_{30}$ (27 days);

$$
M_{T O C}=W_{D} \times M_{T O C}^{D}
$$

Where $\boldsymbol{W}_{\boldsymbol{D}}$ is the dry weight of $180 \mathrm{~g}$ fresh cryoconite, $\boldsymbol{M}_{\boldsymbol{T}}^{\boldsymbol{D} O \boldsymbol{C}}$ is TOC content of in dry cryoconite $\left(1.51 \pm 0.51 \mathrm{mg} \mathrm{g}^{-1}\right.$ dry weight $)$;

$$
W_{D}=W_{F}-W C_{F} \times 1.8
$$

where $\boldsymbol{W}_{\boldsymbol{F}}$ is the weight of fresh cryoconite $(180 \mathrm{~g}), \quad \boldsymbol{W C}_{\boldsymbol{F}}$ is water content in fresh cryoconite $(29.10 \pm 0.97 \mathrm{~g} / 100 \mathrm{~g}$ fresh cryoconite $)$.

\section{Calculation of DOC leaching flux on the whole Tibetan Plateau}

The DOC leaching flux on the whole Tibetan Plateau in one ablation season was calculated according the following equation:

$$
P_{L}=S \times F \times W \times M_{T O C}^{D} \times R_{D O C}^{*}
$$

where $\boldsymbol{P}_{\boldsymbol{L}}$ is the total leaching mass of DOC by cryoconite during night in ablation season, $\boldsymbol{M}_{T}^{\boldsymbol{D}} \boldsymbol{} \boldsymbol{} \boldsymbol{c}$ is the concentration of TOC in the dry cryoconite, F is the fraction of cryoconite coverage on glacier surface (coverage of cryoconite was $\sim 4 \%-6 \%$ of the glacier surface, we adopted the upper limit value of $6 \%$ for the cryoconite coverage on the glaciers of Western China $\left.{ }^{2}\right), \mathrm{W}$ is the weight of cryoconite per square meter (292 $\pm 196 \mathrm{~g} / \mathrm{m}^{2}$ from measurements on the Qiyi Glacier in the Qilian Mountains ${ }^{3}$ ), and $\mathrm{S}$ is the total glacier surface area of Western China (The total area of glaciers in China is $43087 \mathrm{~km}^{2}$ based on the results of the second Chinese glacier inventory ${ }^{4}$, and the ablation area on the glaciers is estimated to be one-half of the total surface area), $\boldsymbol{R}_{\boldsymbol{D} \boldsymbol{D} \boldsymbol{}}^{*}$ is the DOC leaching rate normalized to TOC $(20.32 \pm 0.27 \%)$. 
Table S1. DOC concentration, total number of assigned formulae, and the relative contribution of assigned molecular formulae to each defined compound class and each elemental composition group as revealed by FT-ICR MS for cryoconite DOM from different leached time points, glacial runoff and dry cryoconite.

\begin{tabular}{|c|c|c|c|c|c|c|c|c|c|c|c|c|c|c|}
\hline \multirow{3}{*}{$\begin{array}{c}\text { Leaching } \\
\text { time }\end{array}$} & \multirow{3}{*}{$\begin{array}{c}\mathrm{DOC} \\
(\mathrm{mg} / \mathrm{L})\end{array}$} & \multicolumn{2}{|c|}{ Number of Average } & Aliphatic & \multirow{2}{*}{$\begin{array}{c}\text { Peptide - } \\
\text { like }\end{array}$} & \multicolumn{2}{|c|}{ Unsaturated Unsaturated, } & Polyphenolic & \multirow{2}{*}{$\begin{array}{c}\text { Sugar - } \\
\text { like }\end{array}$} & \multirow{2}{*}{$\begin{array}{l}\text { Condensed } \\
\text { aromatics }\end{array}$} & \multirow{3}{*}{$\begin{array}{c}\mathrm{CHO} \\
\%\end{array}$} & \multicolumn{3}{|c|}{ CHON CHONS CHOS } \\
\hline & & formulae & Mass & $\%$ & & & W oxygen & $\%$ & & & & $\%$ & $\%$ & $\%$ \\
\hline & & & & & $\%$ & $\%$ & $\%$ & & $\%$ & $\%$ & & & & \\
\hline Day 0 & $13.4 \pm 2.7$ & 3714 & 353.1 & 25.9 & 20.1 & 18.1 & 31.8 & 3.4 & 0.1 & 0.6 & 39.7 & 49.3 & 3.3 & 7.7 \\
\hline Day 3 & $7.1 \pm 2.9$ & 3088 & 346.2 & 33.2 & 11.6 & 17.7 & 32.4 & 4.2 & 0.4 & 0.5 & 53.1 & 37.5 & 0.0 & 9.4 \\
\hline Day 6 & $16.0 \pm 6.3$ & 4720 & 359.4 & 24.1 & 16.6 & 14.9 & 39.0 & 4.3 & 0.3 & 0.8 & 42.3 & 52.1 & 1.0 & 4.6 \\
\hline Day 18 & $38.2 \pm 12.6$ & 4354 & 343.4 & 21.3 & 16.4 & 18.4 & 36.4 & 5.9 & 0.3 & 1.3 & 38.7 & 50.6 & 4.1 & 6.6 \\
\hline Day 30 & $57.1 \pm 4.3$ & 5032 & 366.2 & 21.7 & 14.3 & 17.7 & 39.2 & 5.7 & 0.2 & 1.2 & 40.2 & 46.4 & 4.2 & 9.2 \\
\hline $\begin{array}{l}\text { Glacial } \\
\text { runoff }\end{array}$ & $8.1 \pm 1.3$ & 2060 & 377.4 & 38.8 & 8.6 & 22.6 & 25.5 & 1.8 & 0.1 & 0.7 & 62.0 & 25.8 & 0 & 12.1 \\
\hline $\begin{array}{c}\text { Dry } \\
\text { cryoconite }^{1}\end{array}$ & $\begin{array}{c}1.5 \pm 0.5 \\
\mathrm{mg} / \mathrm{g}\end{array}$ & 1520 & 409.0 & 40.5 & 27.4 & 0.36 & 23.0 & 7.7 & 0 & 1.1 & 53.4 & 43.8 & 0 & 1 \\
\hline
\end{tabular}


Table S2. The relative contribution of three designated classes i.e. bio-resistant, bio-labile, and newly-presented in different biochemical compounds (i.e. aliphatic, peptide-like, unsaturated, polyphenolic etc.) during the two leaching stages: $d_{0}$ to $d_{3}$ and $d_{3}$ to $d_{30}$.

\begin{tabular}{|c|c|c|c|c|c|c|c|c|c|c|c|c|}
\hline \multirow{2}{*}{$d_{0}$ to $d_{3}$} & \multirow{2}{*}{$\begin{array}{l}\text { Number of } \\
\text { formulae }\end{array}$} & Aliphatic & $\begin{array}{c}\text { Peptide - } \\
\text { like }\end{array}$ & $\begin{array}{c}\text { Unsaturatec } \\
\text { High }\end{array}$ & Unsaturated, & Polyphenolic & Sugar - & \multirow{2}{*}{$\begin{array}{c}\text { Condensed } \\
\text { aromatics } \\
\%\end{array}$} & \multirow{2}{*}{$\begin{array}{c}\mathrm{CHO} \\
\%\end{array}$} & \multicolumn{3}{|c|}{ CHON CHONS CHOS } \\
\hline & & $\%$ & $\begin{array}{c}\text { like } \\
\%\end{array}$ & $\begin{array}{c}\text { oxygen } \\
\%\end{array}$ & $\begin{array}{c}\text { Low oxygen } \\
\%\end{array}$ & $\%$ & $\begin{array}{c}\text { like } \\
\%\end{array}$ & & & $\%$ & $\%$ & $\%$ \\
\hline Bio-resistant & 2521 & 62.0 & 40.8 & 68.7 & 61.5 & 62.8 & 28.6 & 42.3 & 67.3 & 54.3 & 0.0 & 59.6 \\
\hline Bio-labile & 1193 & 16.4 & 54.4 & 24.3 & 26.0 & 17.3 & 7.1 & 42.3 & 11.9 & 40.2 & 100 & 20.2 \\
\hline $\begin{array}{l}\text { Newly- } \\
\text { presented }\end{array}$ & 567 & 21.6 & 4.8 & 6.9 & 12.6 & 19.9 & 64.3 & 15.4 & 20.8 & 5.5 & 0.0 & 20.2 \\
\hline$d_{3}$ to $d_{30}$ & & & & & & & & & & & & \\
\hline Bio-resistant & 2716 & 62.8 & 40.7 & 58.3 & 45.7 & 42.7 & 57.1 & 21.1 & 61.9 & 45.1 & 0.0 & 49.3 \\
\hline Bio-labile & 345 & 16.1 & 6.0 & 1.9 & 3.2 & 1.7 & 35.7 & 0.0 & 10.5 & 3.0 & 0.0 & 7.6 \\
\hline $\begin{array}{l}\text { Newly- } \\
\text { presented }\end{array}$ & 2289 & 21.1 & 53.3 & 39.8 & 51.2 & 55.6 & 7.1 & 78.9 & 27.6 & 52.0 & 100 & 43.1 \\
\hline
\end{tabular}

Table S3. Summary of general parameters associated with cryoconite DOM during the two leaching stages.

\begin{tabular}{cccc}
\hline $\mathbf{d}_{\mathbf{0}} \mathbf{t o ~ d}_{\mathbf{3}}$ & Bio-resistant & Bio-labile & Newly-presented \\
\hline All formulas & 2521 & 1194 & 567 \\
$\mathrm{H} / \mathrm{C}$ & $1.41 \pm 0.27$ & $1.48 \pm 0.25$ & $1.47 \pm 0.32$ \\
$\mathrm{O} / \mathrm{C}$ & $0.45 \pm 0.13$ & $0.47 \pm 0.14$ & $0.33 \pm 0.19$ \\
$\mathrm{~N} / \mathrm{C}$ & $0.04 \pm 0.06$ & $0.07 \pm 0.06$ & $0.02 \pm 0.04$ \\
$\mathrm{DBE}$ & $6.5 \pm 2.5$ & $6.6 \pm 2.6$ & $6.7 \pm 3.3$ \\
$\mathrm{AI}$ & $0.17 \pm 0.17$ & $0.11 \pm 0.16$ & $0.19 \pm 0.17$ \\
${ }_{\text {mod }}$ & $372.4 \pm 86.8$ & $433.1 \pm 109.6$ & $411.2 \pm 105.5$ \\
$\mathrm{MW}$ & & & \\
$\mathbf{d}_{\mathbf{3}}$ to d & & 345 & 2289 \\
\hline $\mathrm{All}$ formulas & 2716 & $1.63 \pm 0.25$ & $1.30 \pm 0.29$ \\
$\mathrm{H} / \mathrm{C}$ & $1.39 \pm 0.27$ & $0.29 \pm 0.19$ & $0.44 \pm 0.12$ \\
$\mathrm{O} / \mathrm{C}$ & $0.45 \pm 0.14$ & $0.02 \pm 0.05$ & $0.05 \pm 0.05$ \\
$\mathrm{~N} / \mathrm{C}$ & $0.04 \pm 0.06$ & $5.0 \pm 2.6$ & $9.1 \pm 3.3$ \\
$\mathrm{DBE}$ & $6.7 \pm 2.6$ & $0.12 \pm 0.13$ & $0.22 \pm 0.20$ \\
$\mathrm{AI}$ & $0.18 \pm 0.17$ & $396.4 \pm 107.5$ & $462.3 \pm 113.0$ \\
\hline mod & $377.2 \pm 89.3$ & & \\
$\mathrm{MW}$ & & &
\end{tabular}




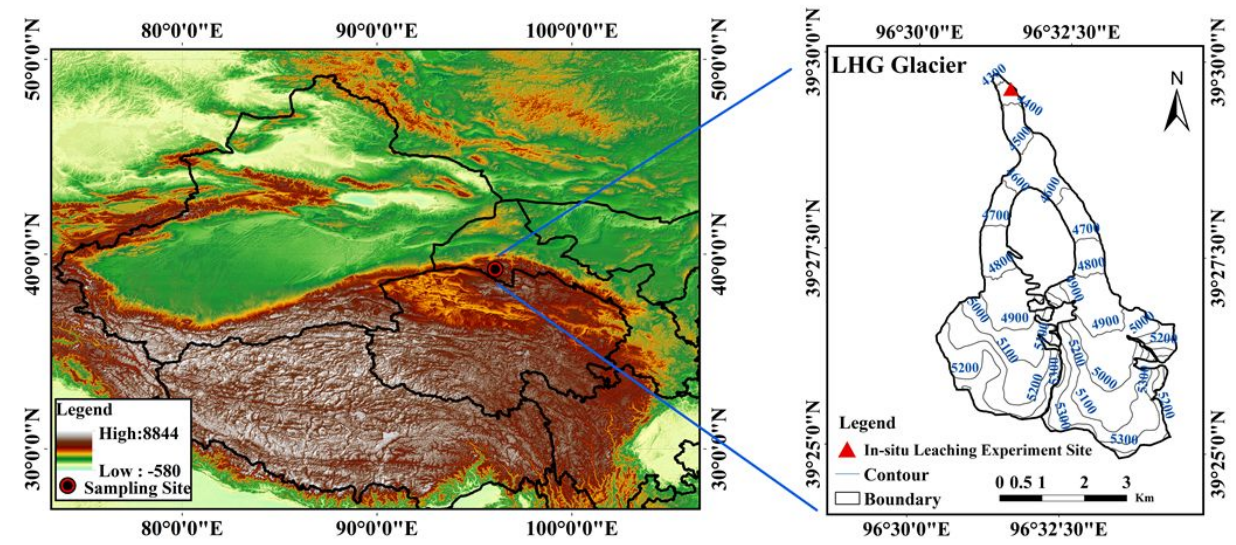

Figure S1. Map of the location of Laohugou Glacier No. 12 (LHG) on the Tibetan Plateau and the site of cryoconite sampling and field leaching (filled triangle) at LHG.

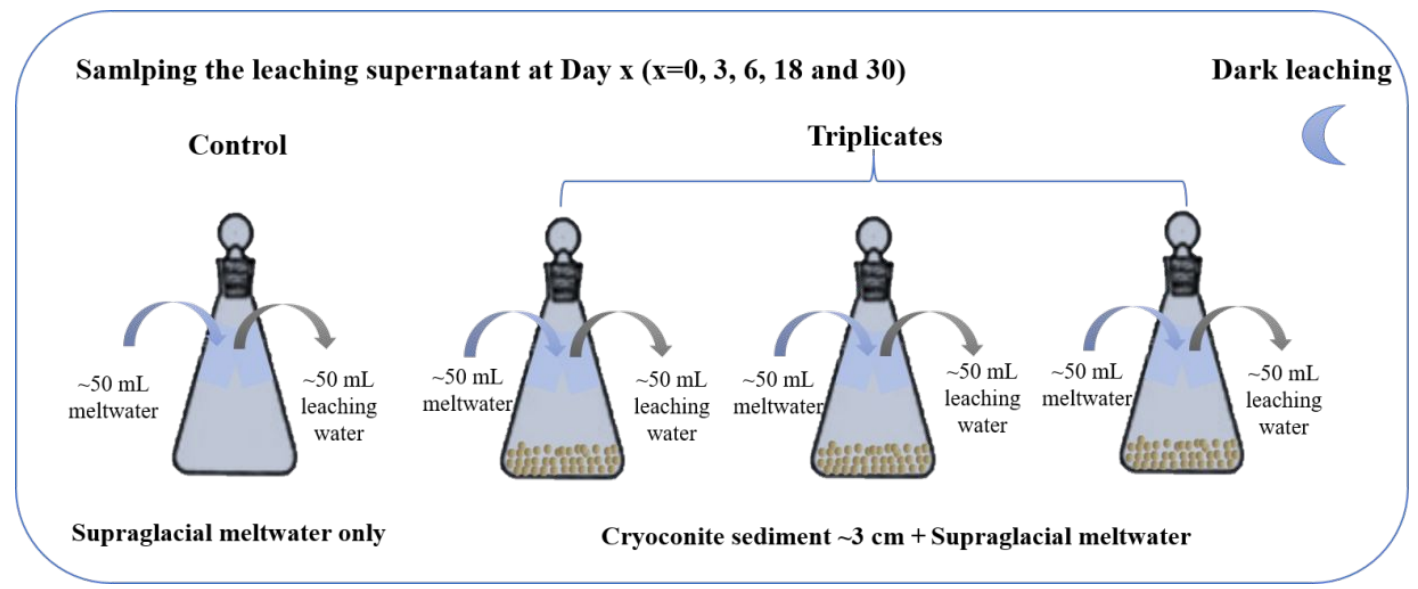

Figure S2. The schematic of the in-situ cryoconite DOM leaching experiment under dark conditions. 

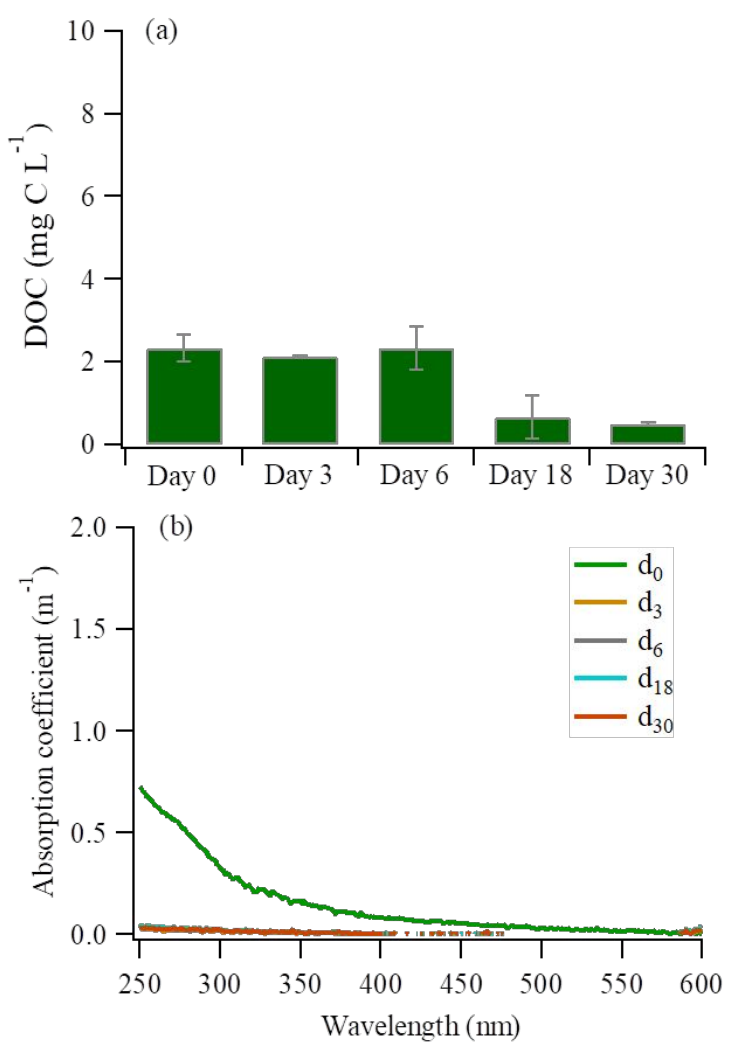

Figure S3. (a) Average DOC concentration of control which only contains supraglacial meltwater at $\mathrm{d}_{0}, \mathrm{~d}_{3}, \mathrm{~d}_{6}, \mathrm{~d}_{18}$ and $\mathrm{d}_{30}$, (b) UV-Vis absorbance spectra of DOM in supraglacial meltwater leached in $\mathrm{d}_{0}, \mathrm{~d}_{3}, \mathrm{~d}_{6}, \mathrm{~d}_{18}$ and $\mathrm{d}_{30}$. The error bars indicate the standard error $(1 \sigma)$. 

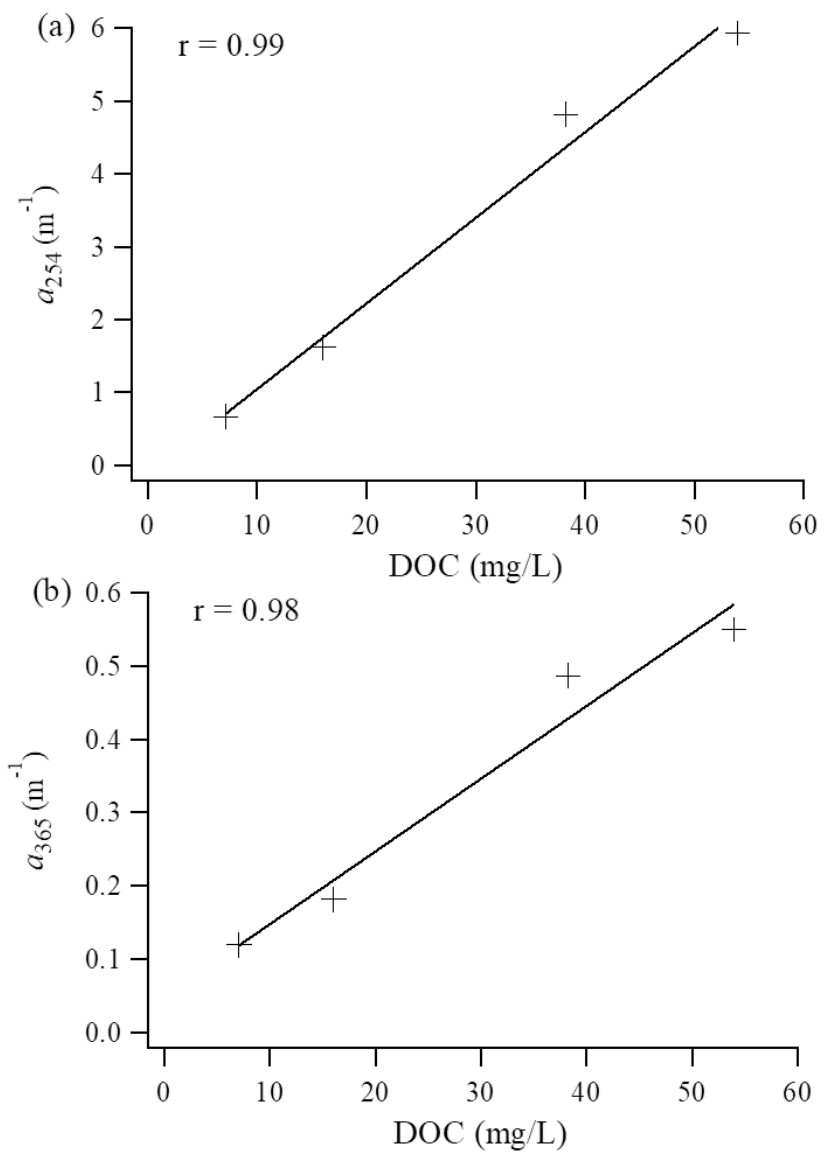

Figure S4. Scatter plots of (a) $a_{254}$ versus dissolved organic carbon (DOC) and (b) $a_{365}$ versus DOC (not including $\mathrm{d}_{0}$ ). 


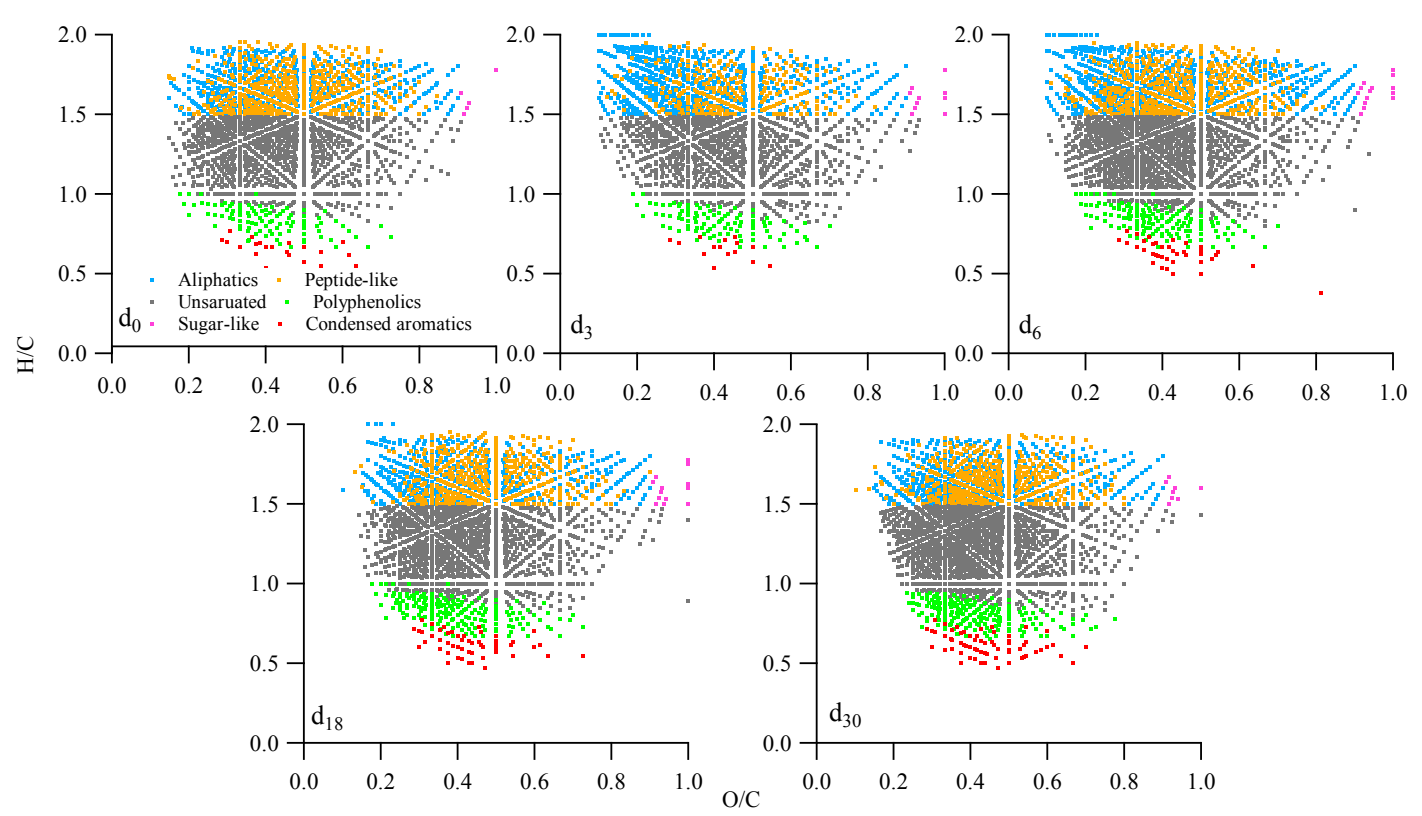

Figure S5. van Krevelen diagrams of cryoconite DOM at $\mathrm{d}_{0}, \mathrm{~d}_{3}, \mathrm{~d}_{6}, \mathrm{~d}_{18}$ and $\mathrm{d}_{30}$. Color in the plots indicate the different classes of biomolecular compounds which were defined as follows: Aliphatics $=\mathrm{O} / \mathrm{C} \leqslant 0.9,1.5 \leqslant \mathrm{H} / \mathrm{C} \leqslant 2.0, \mathrm{~N}=0$; Peptide like $=\mathrm{O} / \mathrm{C} \leqslant 0.9,1.5 \leqslant \mathrm{H} / \mathrm{C} \leqslant 2.0, \mathrm{~N}>0$; Sugar - like $=\mathrm{O} / \mathrm{C}>0.9,1.5 \leqslant \mathrm{H} / \mathrm{C}$ $\leqslant 2.0 ;$ Unsaturated, low oxygen $=\mathrm{O} / \mathrm{C}<0.5, \mathrm{H} / \mathrm{C}<1.5, \mathrm{AI}_{\bmod } \leqslant 0.5$; Unsaturated, high oxygen $=\mathrm{O} / \mathrm{C}>0.5, \mathrm{H} / \mathrm{C}<1.5, \mathrm{AI}_{\bmod } \leqslant 0.5 ;$ Polyphenolic $=0.5<\mathrm{AI}_{\bmod }<0.67$; Condensed aromatics $=\mathrm{AI}_{\bmod } \geqslant 0.67$. 


\section{References:}

(1) Feng, L.; Xu, J.; Kang, S.; Li, X.; Li, Y.; Jiang, B.; Shi, Q., Chemical Composition of Microbe-Derived Dissolved Organic Matter in Cryoconite in Tibetan Plateau Glaciers: Insights from Fourier Transform Ion Cyclotron Resonance Mass Spectrometry Analysis. Environ. Sci. Technol. 2016, 50, (24), 13215-13223.

(2) Swstrm, C.; Mumford, P.; Marshall, W.; Hodson, A.; Laybourn-Parry, J., The microbial communities and primary productivity of cryoconite holes in an Arctic glacier (Svalbard $79^{\circ}$ N). Polar Biol. 2002, 25, (8), 591-596.

(3) Takeuchi, N.; Matsuda, Y.; Sakai, A.; Fujita, K., A large amount of biogenic surface dust (cryoconite) on glacier in the Qilian Mountains, China. Bull. Glaciol. Res. 2005, $22,1-8$.

(4) Guo, W.; Liu, S.; Xu, J.; Wu, L.; Shangguan, D.; Yao, X.; Wei, J.; Bao, W.; Yu, P.; Liu, Q., The second Chinese glacier inventory: data, methods and results. J. Glaciol. 2015, 61, (226), 357-372. 